\title{
がれきの散在する港湾内での情報収集を目指した ロープウェイ式海洋探査ロボット
}

\author{
Ropeway Type Marine Probe Robot \\ Aiming Search and Rescue in the Ocean with Debris
}

\author{
正 塚越秀行（東工大） 正 森庸太朗（東工大） 学 堀江宏太（東工大） \\ 正 北川能（東工大） Reza Ghorbani（ハワイ大学）
}

\begin{abstract}
Hideyuki TSUKAGOSHI, Tokyo Institute of Technology, htsuka@cm.ctrl.titecu.ac.jp Yotaro MORIJ, Kota HORIE, Ato KITAGAWA, Tokyo Institute of Technology Reza GHORBANI, University of Hawaii
\end{abstract}

\begin{abstract}
This paper discusses a ropeway type mobile method aiming to collect information in the ocean with obstacles such as debris and rocks as smoothly as possible. The device to realize it is mainly composed of a fire hose and a gondola probe, which is driven by fluid power using buckling phenomenon of the tube. The big advantage is the gondola has possibility of traversing rocky terrain where wheel types and crawler ones are hard to cross over, because it can go forward by the driving force not against the ground but against the hose.
\end{abstract}

Key Words: Search and Rescue Robot, Flexible Actuator, Sliding Actuator, Fluid powered ropeway

\section{1. 緒言}

東日本大震災により津波で甚大な被害を受けた港湾海 域内には、堤防や灯台が大きなダメージを受けたものが 数多く存在すると予測されている。2 次災害の軽減、お よび新たな非常事態に備えて、ダメージを受けた海域内 の建造物の被害状況を正確に把握し、補強工.事を早急に 行う必要が求められている。しかし、海域内にはいまだ にがれきが散在し、波でがれきが常時動く劣悪環境では、 ダイバーによる潜水探査は困難である一方、通常の海洋 探査ロボットはがれきや岩などの障害物にスタックす ると回収は難しくし、そのうえ波打ち際での安定な移動 が困難である。そのため、海域内・海底内からの情報収 集作業は効率的に進んでいないのが現状である。

そこで本研究では，筆者らが半壇家屋内の移動探査方 法として提案した「流体ロープウェイ」と名付けた移動 方法を上記劣悪環境下での海洋探査に導入することと した。本報では, まず, 導入する移動方法の基本構成と 運用手順を述べたのち，「 $\Lambda$-drive(ラムダドライブ)」 と称する駆動原理に基づいてホース上をスムーズに移 動するための構造を紹介する. 次に, 開発した試作機に より行った実験について述べる.

\section{2. 流体ロープウェイの概念}

導入する「流体ロープウェイ」は, 次の 3 つの基本要 素から構成される.すなわち, 内部に流体エネルギーを 供給する 1 本の消防ホース, 探査機器を搭載したゴンド ラ, およびホースの折り返し点で海洋の所定の箕所に固 定するためのフロートとアンカーである. ホースは, フ ロートにてU ターンするように取り付けられているた め, オペレータの手元でホースを双方から印加できる構 造となっている.
流体ロープウェイの基本的な運用は, 以下 3 つの手順 に沿って進められる(Fig. 1)。i)岸辺にいるオペレータ が，目標海域内のロープ付きフロートおよびアンカーを 投撙装置により投げいれる.アンカーは着水すると水の 重みも利用してさらに質量が増加する構造となってい る。 ii）オペレータがロープを率引すると、消防ホース が海洋内に設定される。Iii）ホース内に流体エネルギー を供給することにより,ゴンドラをホースに沿って双方 向にスライドさせる.この際, ゴンドラから送信される 情報を受信しながら探査する．iv）探査終了時点で, ゴ ンドラをオペレータのもとに帰還させたのち，一端を引 つ張りながらホースを回収する。また、i）ii）の作業に おいてフロートを小型船に置き換え、がれきの存在しな い海域を迂回しながらホースを所定の位置まで搬送す る方法も考えられる.

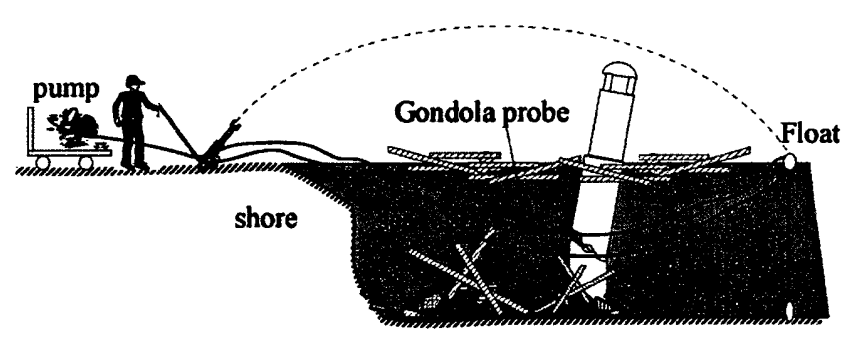

Fig.1 Image of the fluid powered ropeway at disastrous ocean

流体ロープウェイの最大の特徴は、動力源をゴンドラ 内部に搭載せず、代わりにホース内の流体エネルギーを 利用してゴンドラを推進させる点にある。すなわち、ゴ ンドラに内蔵されたスライダとよぶ軽量な構造体で、ホ 一ス内の流路を遮断しながら推力を生成する。また、通 常のロープウェイと異なり、ホースは外部環境に対して 不動のため、四凸環境でもホースに摺動摩擦が生じにく い構成である。 


\section{3.ゴンドラの駆動方法}

\section{$3.1 \Lambda$-drive $の$ 導入}

ゴンドラを駆動するスライダの構造として、いくつか の候補が考えられる。ホースとスライダ閒の摩擦損失を 極力低減し、長いホースに沿ってスライダがスムーズに 移動するために、以下に述べる駆動原理を導入した。 その駆動原理は、ホースとスライダの要素から成る簡 便な構造に基づいたものである。使用する消防ホースは、 無加圧状態では断面が偏平形状を形成し、加圧状態では 断面周長をほぼ一定に保ちつつ断面が円形に近づく特 徵を有するものとする。スライダは、主に摩擦低減のた めのローラーと座屈保持のためのストッパから構成さ れている。Fig. 2のようにホース内の一方を加压すると、 座屈点まで流体は流れるものの、座屈点より下流側は流 路が遮断されるため流体は流れない。さらに加圧し続け ると、座屈点を含む曲げ部とともにスライダも下流側に 駆動される。曲げ部の形状とギリシャ文字 $\Lambda$ （ラムダ） との類似性から、この構成を $\Lambda$-drive $\mathrm{e}^{22}$ と名付けてきた。

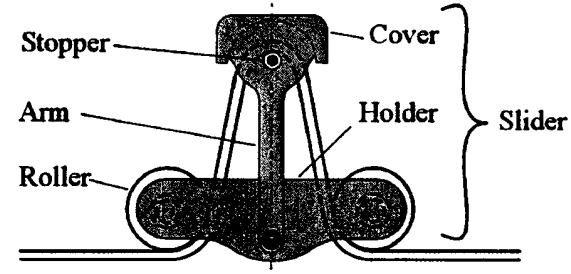

(a) non-pressurized condition

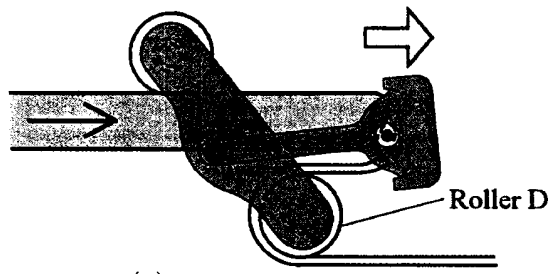

(b) pressurized condition

Fig. 2 Structure of the slider driven by $\Lambda$-drive

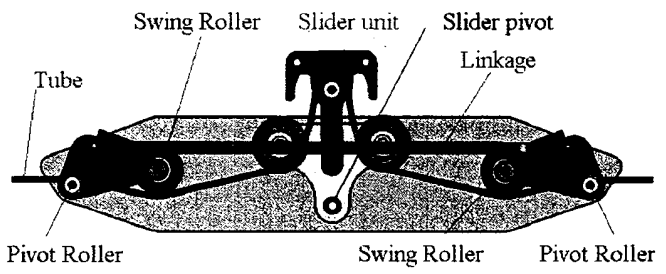

(a) non-pressurized condition

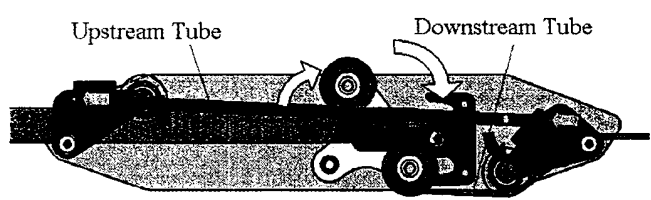

(b) pressurized condition

Fig. 3 Structure of the gondola

\section{2 ゴンドラの内部構造}

ゴンドラに取り付けられたスライダにおいて、下流側 のホースが、上流側のホースおよびゴンドラの長手方向 と常に平行に保たれる図 4 に示す機構を導入した。これ により、推力方向とスライダの移動方向が一致し、駆動 效率の向上が望めるからである。詳細は文献 ${ }^{[1]}$ れたい。

\section{4. 海洋での探査実験}

試作したスライダはFig. 4 に示寸構成となっており、 質量は $2.7 \mathrm{~kg}$ である。内径 $50 \mathrm{~mm}$ の消防ホース内に $1.2 \mathrm{MPa}$ の水圧を印加した場合、 $1.28 \mathrm{kN}$ の駆動力を生成するこ とができる。実際の実験では、0.2MPa の水道圧で加圧 し、推力 $200 \mathrm{~N}$, 推進速度 $300 \mathrm{~mm} / \mathrm{s}$ を生成できることが 確認された。なお、本試作機を地上で駆動させた場合、 Fig. 5 (右)に示すように鉛直上向きにも登攀可能である ことが確認された。

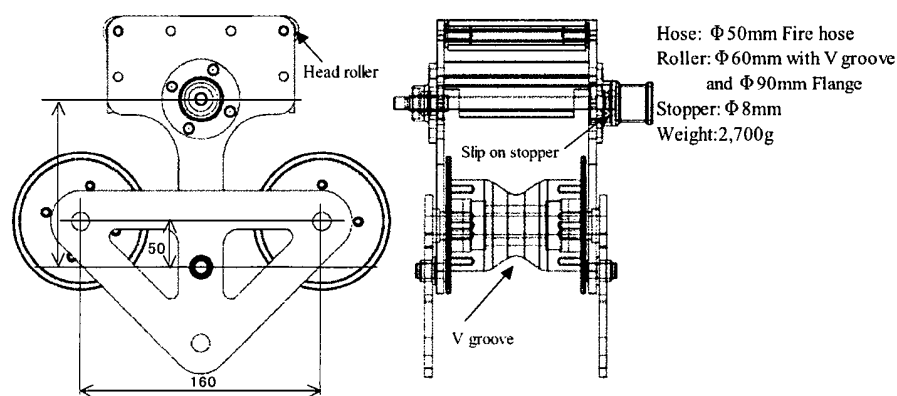

Fig.4 Mechanism of the slider for Fire hose.
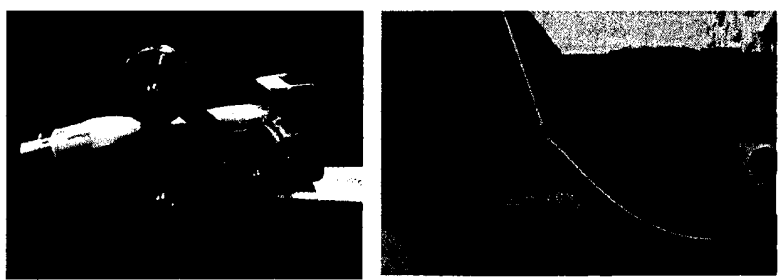

Fig. 5 Prototype of the slider and climbing motion on the wall.
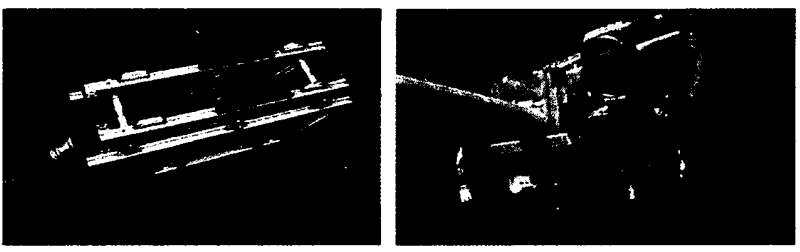

Fig.6 Developed Gondola

Table 1 Specification of the developed gondola

\begin{tabular}{|l|l|}
\hline Length & $920 \mathrm{~mm}$ \\
Height & $282 \mathrm{~mm}$ \\
Width & $250 \mathrm{~mm}$ \\
\hline Weight & $21 \mathrm{~kg}$ \\
\hline Pressure & $0.2 \mathrm{MPa}$ \\
\hline
\end{tabular}


上記のスライダを用いて試作したゴンドラ探査機は、Fig. 6 および Table1に示す通りの構成となった。探查機にはビデオ カメラが装着されており、収集した画像情報を記録できるよ うになっている。実験の結果、Fig. 7 に示すように岩場の露出 した浅瀬でも安定に移動できることが確認された。

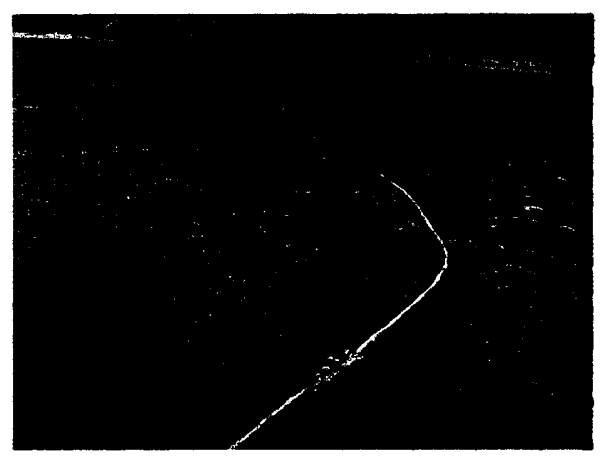

(a) Before crossing over the rocks

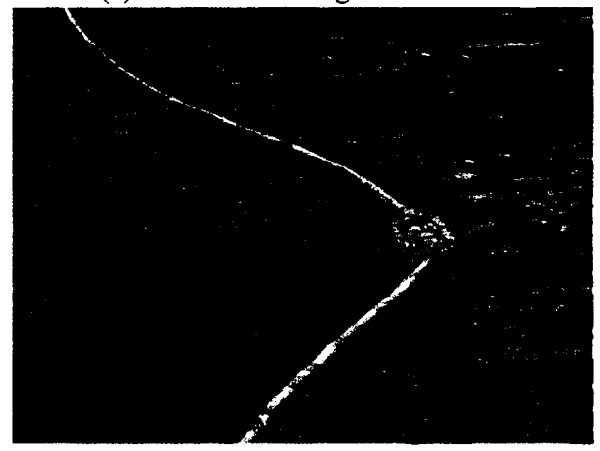

(b) After crossing over the rocks

Fig.7 Experiment in the ocean with rocks

\section{6. 結}

本論文では，がれきの散在した海域内の情報収集を迅 速・安全に行う無人探査ロボットの移動手段として, 流 体ロープウェイと名付けた移動方式を紹介し, その運用 方法や特徴を述べた. 今後は, 受動回転式クローラをゴ ンドラの外面に装備するなどにより, 外部環境とゴンド ラとの摺動摩擦を減らす方策，ii）直視できないゴンド ラの位置をオペレータに知らせる方法, などを検討する 予定である。

\section{謝辞}

本研究の一部は，消防防災科学技術推進制度の诟究課 題「危険建物内の迅速安全な情報収集を行う投擲型探査 装置の開発」の研究助成を受けて行われた.

\section{参文 嗝}

1) Yotaro Mori、 Hideyuki Tsukagoshi、Ato Kitagawa "Fluid Powered Ropeway: Self-propelled Probe Sliding Along Flexible Tube" Journal of Robotics and Mechatronics、Vol.23、 No.2、215-224 (2011)

2）森庸太朗、塚越秀行、北川能 “柔軟偏平チューブに沿ってスラ イドする流体アクチュエータ（第 1 郝、 $\Lambda$-drive の提案とその動
作解析）"日本フルードパワーシステム学会論文集、第 41 巻、 第 5 号、98-105(2010)

3) Eyri Watari、 Hideyuki Tsukagoshi、 and Ato Kitagawa "Novel Method to Throw a Tube Into High Altitudes for a Throw and Collect Rescue Inspector" Proceedings of the 13th International Conference on Climbing and Walking Robots (CLAWAR) ande the Support Technologies for Mobile Machines、 pp.1314-1322 (2010)

4）㴊上和峻、ワタリエイリ、塚越秀行、北川能 “危険建物内のレ スキュー活動を支援する投擲式吸着体の開発”ロボティクス・ メカトロニクス講演会 2011、2Al-J11(2011)

5) Toshio Takayama and Shigeo Hirose "Development of "Souryu I \& II" -Connected Crawler Vehicle for Inspection of Narrow and Winding Space" Journal of Robotics and Mechatronics、Vol.15、 No.1 (2003)

6) Hideyuki Tsukagoshi、Yotaro Mori、Masashi Sasaki、 Takahiro Tanaka、 and Ato Kitagawa "Development of Jumping \& Rolling Inspector to Improve the Debris-traverse Ability “ Journal of Robotics and Mechatronics、Vol.15、 No.5 (2003)

7) Hideyuki Tsukagoshi、Hiroyuki Chiba、 Ato Kitagawa "Gel-type Sticky Mobile Inspector to Traverse on the Rugged Wall and Ceiling" IEEE International Conference on Robotics and Automation、 FrA2.5 (2009)

8) Kevin S.Pratt、Robin R.Murphy、 Jennifer L.Burke、Jeff Craighead, Chandler Griffin、 Sam Stover "Use of Tethered Small Unmanned Aerial System at Berkman Plaza II Collapse", Proceedings of the IEEE International Workshop on Safety Security and Rescue Robotics、pp.134-139(2008) 